$\mathrm{A} \int_{\text {ass }} \underset{0976-272 \times \mathrm{x}}{\mathrm{H}}$

Article history :

Received : 12.05.2014

Revised : 07.10.2014

Accepted : 21.10.2014
THE ASIAN JOURNAL OF HORTICULTURE

Volume 9 | Issue 2 | Dec., 2014|347-351

Visit us -www.researchjournal.co.in

\title{
Influence of trickle fertigation on growth and physiological attributes of hybrid okra [Abelmoschus esculentus (L.) Moench]
}

Members of the Research Forum

Associated Authors:

${ }^{1}$ Department of Horticulture, P.J.N.

College of Agriculture and Research

Institute, Karaikal, PUDUCHERRY

(U.T.) INDIA

${ }^{2}$ Department of Soil Science and Agricultural Chemistry, P.J.N. College of Agriculture and Research Institute,

Karaikal, PUDUCHERRY (U.T.) INDIA

Author for correspondence : E. VENKADESHWARAN

Department of Horticulture, P.J.N.

College of Agriculture and Research

Institute, Karaikal, PUDUCHERRY

(U.T.) INDIA

Email: e.venkadeshwaran@gmail.com

\section{E. VENKADESWARAN, V. SUNDARAM'1 AND R. SANKAR ${ }^{2}$}

ABSTRACT : An experiment was conducted to compare the effect of conventional fertilisers and water soluble fertilisers at varying frequency interval of application on growth and physiological attributes of okra [Abelmoschus esculentus (L.) Moench]. The experiment was laid out in a Randomised Block Design with two control involving ten treatments in a factorial way and was replicated thrice. Among the treatment combinations, the plot receiving daily fertigation of water soluble fertilisers $\left(\mathrm{S}_{1} \mathrm{~F}_{1}\right)$ had recorded the maximum plant height at final harvest $(136.80 \mathrm{~cm})$, shortest inter nodal length $(4.46 \mathrm{~cm})$, maximum leaf area index (2.04) and the highest dry matter production $\left(8.23 \mathrm{t} \mathrm{ha}^{-1}\right)$. However, no significant difference could be observed for days to flowering, number of primary branches plant ${ }^{-1}$ at flowering as well as final harvest and node of first flower appearance.

KEY WORDS : Fertigation, Drip irrigation, Water soluble fertilisers, Conventional fertilisers, Fertigation frequency

HOW TO CITE THIS ARTICLE : Venkadeshwaran, E., Sundaram, V. and Sankar, R. (2014). Influence of trickle fertigation on growth and physiological attributes of hybrid okra [Abelmoschus esculentus (L.) Moench]. Asian J. Hort., 9(2) : $347-351$. 